\title{
Floristic study of the bryophytes of an evergreen broad-leaved forest in the vicinity of Baekyaki Oreum in Gujwa-Seongsan Gotjawal, Jejudo Island
}

\author{
Eun-Young YIM* and Hyungsoon CHOI \\ Warm Temperate and Subtropical Forest Research Center, National Institute of Forest Science, Seogwipo 63582, Korea
}

(Received 30 August 2020; Revised 20 September 2020; Accepted 23 September 2020)

\begin{abstract}
This study presents a survey of the bryophytes of evergreen broad-leaved forest near Baekyaki Oreum in Gujwa-Seongsan Gotjawal in the eastern part of Jejudo Island, Korea. A total of 53 taxa belonging to Bryophyta (11 families 26 genera 39 species) and Marchantiophyta ( 9 families, 9 genera 14 species) were determined, and the liverwort index was found to be $26.4 \%$. The predominant life-form was the mat type. The rates of bryophytes dominating at mesic to hygric sites were higher than those of bryophytes, which were mainly observed in xeric habitats. These values indicate that the forest areas in this study area have a high density level. Upon an investigation of the substrates, bryophytes on rocks were most diverse. It was also found that volcanic rock masses of various sizes lay scattered over the study area and offer numerous micro-habitats for bryophytes. This is related to the characteristics of Gotjawal. We consider that more detailed studies should be conducted on regional scales to establish the bryophyte flora of Gotjawal and the evergreen broad-leaved forests of Jejudo Island.
\end{abstract}

Keywords: bryophyte, Gujwa-Seongsan Gotjawal, liverwort index, life-form

Jejudo Island was formed by volcanic activity and has unique topological and geological features. In this unique volcanic terrain, forests established on lava flow are scattered around the island, known as "Gotjawal," a newly coined compound word coming from dialects spoken on Jejudo Island (Jeju Special Self-Governing Province, 2009; Yoon, 2014). Recently, it has become known that Gotjawal is an area inhabited by various plants and animals where unique and various types of ecosystems are also sustained; the area also contains natural waterways of the type necessary to recharge underground water, and it has high preservation value (Jeon et al., 2012; Kang et al., 2013; Yoon, 2014; Jeong, 2015). However, few floristic studies of bryophytes have been conducted, except for those concerning on Seonheul Gotjawal (Dongbaek-dongsan) in the northeastern part of the island by Yim et al. (2013), on Aewol Gotjawal (Subtropical Forest of Nabeup-ri) in the northwestern area by Yim and Hyun (2018), and on Hangyeong Gotjawal (Cheongsu-ri) in the southeastern part of the island by Yim et al. (2019).
The area and range of the Gotjawal terrain have not yet been established (Jeon et al., 2015). According to Song (2000), who first described Gotjawal, Gotjawal can be divided into four major types of terrains. These were termed Gujwa-Seongsan, Jocheon-Hamdeok, Hangyeong-Andeok, and Aewol. The Jeju Special Self-Government Province (2009) adds GyoraeHannam Gotjawal to the four terrains, making the total five (Fig. 1). Among them, the Gujwa-Seongsan Gotjawal terrain is suggested to be divided into four lava flow areas: JongdalHandong Gotjawal, Sehwa Gotjawal, Sangdo-Hado Gotjawal, and Susan Gotjawal (Song, 2000). It has been considered that these lava flows were formed by four corresponding Oreum (a small extinct volcanic cone in Jejudo Island). The JongdalHandong Gotjawal lava flow is distributed from Donggeomun Oreum to the coastal lowlands $30 \mathrm{~m}$ above sea level toward Handong-ri, over a total length of $11 \mathrm{~km}$. The Sehwa Gotjawal lava flow starts at Darangshi Oreum and is distributed over a total length of $4.7 \mathrm{~km}$. The Sangdo-Hado Gotjawal lava flow is distributed over a total length of approximately $5.6 \mathrm{~km}$,

\footnotetext{
*Author for correspondence: curie580@korea.kr
} 


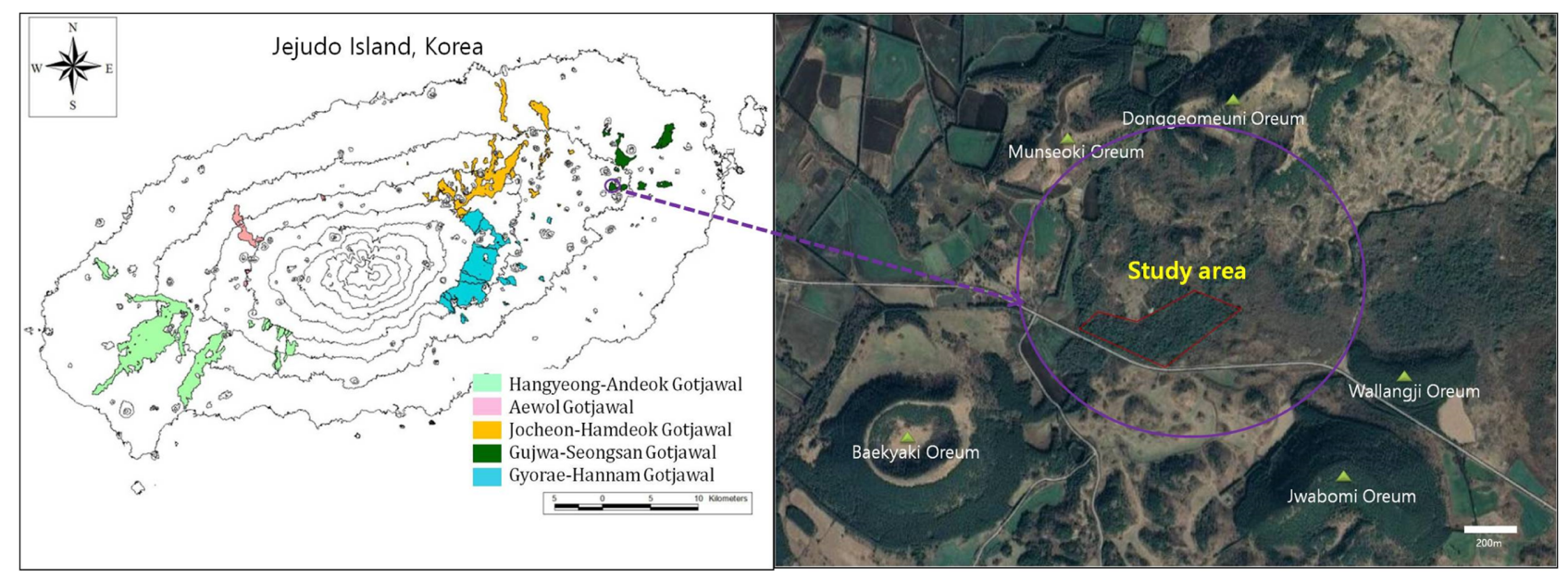

Fig. 1. Map showing the location of the study area and distribution of the Gotjawal terrains, Jejudo Island, Korea. Gotjawal terrains designated by the Jeju Special Self-Governing Province (1997) are indicated by the colored areas.

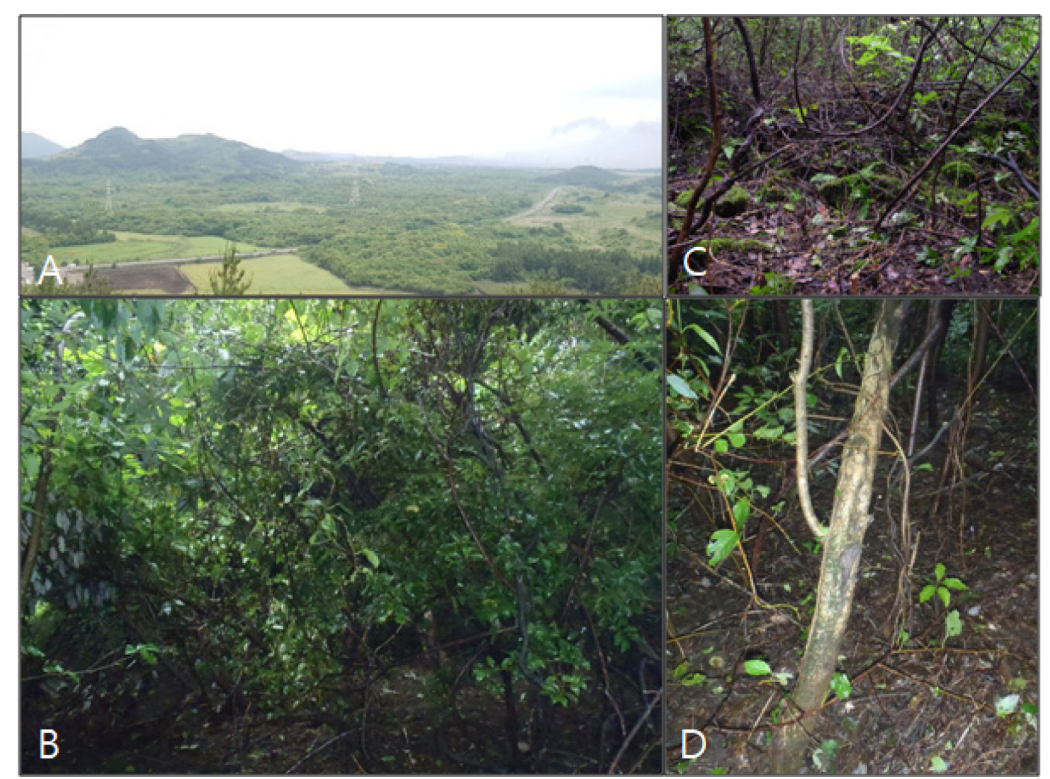

Fig. 2. Pictures showing the characteristics of the evergreen broad-leaved forest in the vicinity of Baekyaki Oreum in Gujwa-Seongsan Gotjawal, Jejudo Island. A. Panoramic view of the evergreen forest from the top of Baekyaki Oreum. B. Vegetation. C. Bryophytes on rocks. D. Bryophytes on bark.

starting from Yongnuni Oreum and ending near Jimibong Oreum. Finally, the Susan Gotjawal lava flow starts around the vicinity of Gungdaeak Oreum $50 \mathrm{~m}$ above sea level in the western area of the village of Susan-ri, running for more than $5.5 \mathrm{~km}$ (Song, 2000). However, Ahn et al. (2015) found that Gujwa-Seongsan Gotjawal was formed by four sequential eruptions at Donggeomun Oreum. The lava flows from the first eruption are distributed in parts of Jongdal-Handong Gotjawal, Sangdo-Hado Gotjawal, and Sehwa Gotjawal. The second flows are distributed along the direction of Sangdo-
Hado among the three forked flows of the first lava flows. The third flows are distributed from Jongdal-Handong Gotjawal to the vicinity of the Bijarim Forest, and the fourth flows are distributed from the south of Donggeomun Oreum toward the east. These lava flows are located in the vicinity of Baekyaki Oreum and are widely known as Baekyaki Oreum Gotjawal or Susan Gotjawal. In this area, evergreen broad-leaved forests are linearly distributed along the uneven terrain and unlike other Gotjawal terrains, the dominant tree species are not evergreen oaks but plants of the family Lauraceae. It has also 
been found that the deciduous trees such as Celtis sinensis Pers. and Mallotus japonicus (L. f.) Mu?ll. are mixed throughout this forest. In addition, in the lower layer of the forest, the ratio of exposed rocks is high, and ferns, such as Arachniodes aristata (G. Forst.) Tindale, A. standishii (T. Moore) Ohwi, and Crepidomanes latealatum (Bosch) Copel grow, as do flowering plants such as Ardisia crenata Sims, A. japonica (Thunb.) Blume, and Rubus buergeri Miq. The adjacent area is used as pasture, where Miscanthus sinensis Andersson, Ligustrum obtusifolium Siebold \& Zucc., Euonymus alatus (Thunb.) Siebold, and M. japonicus etc. are densely distributed. The secondary forest of deciduous broadleaved trees formed around this area is dominated by Pourthiaea villosa (Thunb.) Decne., Zelkova serrata (Thunb.) Makino, and C. sinensis, among others (Fig. 2A, B).

The purpose of this study was to investigate the bryophyte flora of the evergreen broad-leaved forest in the vicinity of Baekyaki Oreum in Gujwa-Seongsan Gotjawal. Furthermore, this study contributes to the literature on the bryophyte flora of Gotjawal and evergreen broad-leaved forests on a regional scale and provides basic data pertaining relevant indicator species.

\section{Materials and Methods}

\section{Field surveys}

Field surveys were conducted in an evergreen broad-leaved forest in the vicinity of Baekyaki Oreum in Gujwa-Seongsan Gotjawal, with an area of approximately $75,453 \mathrm{~m}^{2}$ (Fig. 1), four times from August of 2011 to August of 2018. The study area is located between Donggeomeuni Oreum, Baekyaki Oreum, and Jwabomi Oreum and belongs to Jongdal-ri, Gujwaeup, Jeju-si, and Seongeup-ri, Pyoseon-myeon, Seogwipo-si.

\section{Identification, nomenclature and arrangement of taxa}

The samples collected in the investigated area were identified at the species level with macroscopic morphology and microscopic features using relevant literature (Iwatsuki and Mizutani, 1972; Inoue, 1974, 1976; Choe, 1980; Noguchi, 1987, 1988, 1989, 1991, 1994; Gao et al., 1999; Iwatsuki, 2001; Li et al., 2001; Wu et al., 2002; Cao et al., 2003). Voucher specimens were deposited in the herbarium of the Warm Temperate and Subtropical Forest Research Center in Korea (WFRC). Only one collection number per taxon was cited to avoid repetition on the floristic list. The nomenclature and arrangement of the taxa utilize the systems proposed by Goffinet et al. (2009) and Crandall-Stotler et al. (2009) for mosses and liverworts, respectively.

\section{Life-forms and substrates}

The life-forms of the bryophytes in the study area were estimated using Mägdefrau (1982), and they were found to be on the floristic list for each taxon. The records of substrates for each taxon were included in this list.

\section{Number of bryophyte taxa and liverwort index}

We compared the number of taxa and the liverwort index of the evergreen broad-leaved forest in the vicinity of Baeakyaki Oreum with other localities based on the available literature [i.e., Deogyusan Mt. (Choi et al., 2010; Yoon et al., 2011), Sobaeksan Mt. (Korea National Park Research Institute, 2016a), Gayasan Mt. (Korea National Park Research Institute, 2016b), Taebaeksan Mt. (Korea National Park Research Institute, 2018), Jirisan Mt. (Korea National Park Research Institute, 2019a), Sokrisan Mt. (Korea National Park Research Institute, 2019b), Dongbaek-dongsan (Yim et al., 2013), Subtropical Forest of Nabeup-ri (Yim and Hyun, 2018), and the evergreen broad-leaved forest of Cheongsu-ri at Hangyeong Gotjawal (Yim et al., 2019)]. The liverwort index, which is based on the fact that liverworts and hornworts tend to prefer more humid conditions compared to mosses, was calculated as follows (Nakanishi, 2001):

$$
\text { Liverwort index }(\%)=\frac{\text { No. of liverworts }+ \text { No. of hornworts }}{\text { Total no. of liverworts }} \times 100
$$

\section{Results and Discussion}

\section{The number of taxa and the liverwort index}

A total of 53 taxa belonging to Bryophyta (11 families 26 genera 39 species) and Marchantiophyta (9 families 9 genera 14 species) were determined (Appendix 1). A comparison of the results of the numbers of taxa indicated that the evergreen broad-leaved forest in the vicinity of Baeakyaki Oreum has a larger area than the Subtropical Forest of Nabeup-ri, but also has lower species diversity (Table 1).

The liverwort index is based on findings indicating that liverworts and hornworts tend to prefer more humid conditions than mosses. Therefore, it is useful to compare air humidity levels between different sites (Nakanishi, 2001). The liverwort index of the evergreen broad-leaved forest in the vicinity of Baekyaki Oreum showed a humidity level of $26.4 \%$, demonstrating that the air humidity of investigated area was lower than all of the mountain and Gotjawal areas, apart from the evergreen broad-leaved forest of Cheongsu-ri (Table 1). We consider that more detailed studies of the bryophyte flora of Korea should be conducted on a regional scale. 
Table 1. Comparisons of the bryophyte species richness levels and liverwort indexes of the evergreen broad-leaved forest in the vicinity of Baeakyaki Oreum and other localities.

\begin{tabular}{lccc}
\hline \multicolumn{1}{c}{ Locality } & Area $\left(\mathrm{km}^{2}\right)$ & No. of species & Liverwort index \\
\hline Gotjawal area & & & \\
Evergreen broad-leaved forest in the vicinity of Baeakyaki Oreum (Gujwa-Seongsan Gotjawal) & 0.075 & 53 & 26.4 \\
Dongbaek-dongsan (Seonheul Gotjawal) & 1.420 & 85 & 27.0 \\
Evergreen broad-leaved forest of Cheongsu-ri (Hangyeong Gotjawal) & 0.501 & 72 & 23.6 \\
Subtropical Forest of Nabeup-ri (Aewol Gotjawal) & 0.034 & 63 & 30.2 \\
Mountain area & & & \\
Jirisan Mt. & 483.022 & 218 & 49.5 \\
Sobaeksan Mt. & 322.011 & 236 & 41.9 \\
Deogyusan Mt. & 231.650 & 311 & 40.8 \\
Sokrisan Mt. & 274.766 & 130 & 42.3 \\
Gayasan Mt. & 76.256 & 173 & 37.6 \\
Taebaeksan Mt. & 70.052 & 275 & 38.9 \\
\hline
\end{tabular}

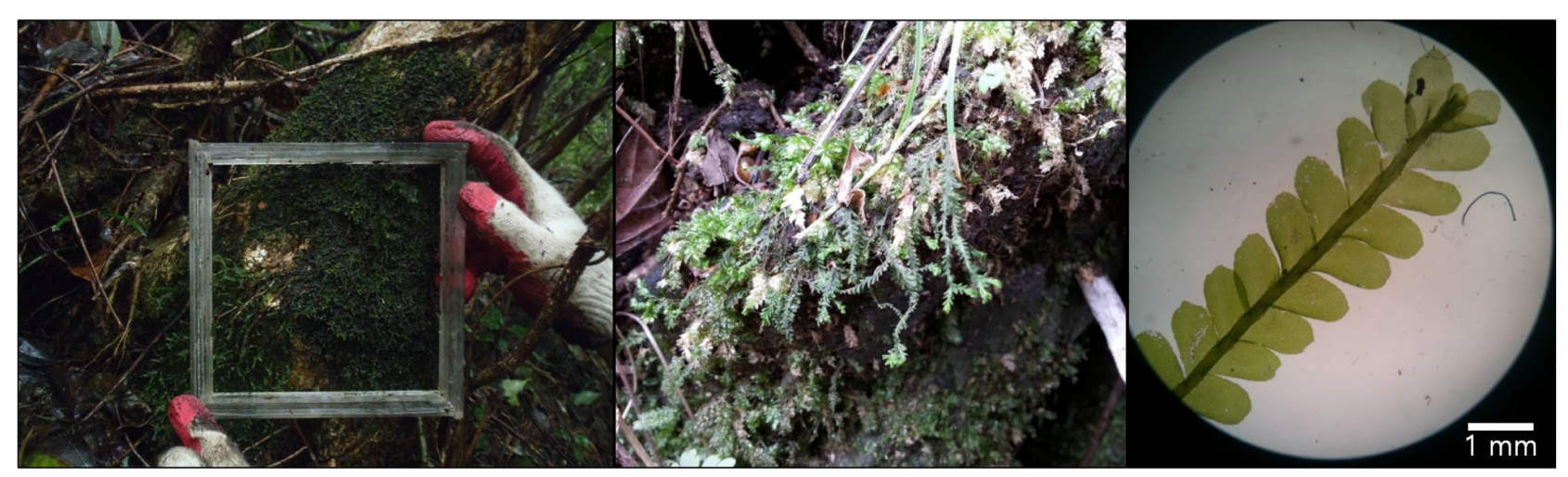

Fig. 3. Plagiochila shangaica Steph. found in the study area.

\section{Remarkable species}

Plagiochila shangaica Steph. (Hae-an-nal-gae-i-kki), Choi et al. (2012), newly reported from Korean flora, was found in this study area (Fig. 3). This liverwort inhabits moist rocks on Jejudo Island, Oenarodo Island and Geojedo Island, among others, and is distributed in China, Japan, and Vietnam (Choi, 2013; Shu et al., 2017). The centers of diversity of Plagiochila are in Southeast Asia and the Neotropics (So, 2001). P. shangaica is designated and managed as a rare plant in Japan (Ministry of the Environment Government of Japan, 2020). The habitat of this species was unknown except for Andeok Valley on Jejudo Island, and this marks the first time it has been found in Gotjawal terrains thus far. Therefore, it is considered that research on this species as a climate change indicator species and rare plant is necessary.

\section{Life-forms}

We estimated the life-forms for each taxon in the study area, as presented in Table 2. The predominant life-form was the mat type (19 species, $35.8 \%$ ), followed by the weft (18 species, $34.0 \%$ ), tall turf (10 species, 18.9\%), fan (3 species, 5.7\%), tail (2 species, $3.8 \%$ ), and short turf types ( 1 species, $1.9 \%)$. We analyzed the results based on the relationship between the adaptive strategy and life-form of bryophytes according to Kürschner (2004), Uyar et al. (2007), and Glime (2017). As a result, the rates of mostly pleurocarpous bryophytes (the mat, weft, fan, and tail life forms) dominating at mesic to hygric sites amounted to $79.2 \%$, whereas mostly acrocarpous bryophytes (the tall turf and short turf life forms), mainly observed in xeric habitats, amounted to $20.8 \%$ (Fig. 2, Appendix 1). These values indicate that the forests in this study area have high density levels. 
Table. 2. Number of taxa and percentage composition according to the life-forms of bryophytes in the study area.

\begin{tabular}{lc}
\hline \hline \multicolumn{1}{c}{ Life-forms } & No. of taxa (\%) \\
\hline Xeric habitat type & $11(20.8)$ \\
Short turfs & $1(1.9)$ \\
Tall turfs & $10(18.9)$ \\
Mesic to hygric site type & $42(79.2)$ \\
Tails & $2(3.8)$ \\
Fans & $3(5.7)$ \\
Mats & $19(35.8)$ \\
Wefts & $18(34.0)$ \\
\hline
\end{tabular}

Table 3. The number of taxa according to the substrate in the study area.

\begin{tabular}{lc}
\hline \multicolumn{1}{c}{ Substrate } & No. of taxa \\
\hline Specific to only one substrate & 28 \\
Epilithic & 1 \\
Epiphytic & 1 \\
Epixylous & 1 \\
On the soil & \\
Common to two or more substrates & 9 \\
Epilithic and epiphytic & 2 \\
Epilithic and on the soil & 1 \\
Epilithic and epixylous & 1 \\
Epiphytic and epixylous & 2 \\
Epilithic, epiphytic and epixylous & 2 \\
Epilithic, epiphytic and on the soil & 1 \\
Epilithic, epixylous and on the soil & 4 \\
Epilithic, epiphytic, epixylous and on the soil & 53 \\
\hline$\quad$ Total &
\end{tabular}

\section{Substrate pattern}

We estimated the substrates for each taxon to investigate the distribution pattern. The numbers of taxa according to the substrate are presented in Table 3. Upon an investigation of the substrates, bryophytes on the rocks were found to be most diverse, at 49 taxa, followed by bark (19 taxa) and decayed tree and soil (10 taxa, each). These results appear to stem from the fact that volcanic rock masses of various sizes are scattered over the study area, offering numerous micro-habitats for bryophytes due to one of the characteristics of Gotjawal, i.e., the presence of rocks of various sizes that are scattered randomly (Fig. 2C, D).
ORCID: Eun-Young YIM https://orcid.org/0000-0002-37334798; Hyungsoon CHOI https://orcid.org/0000-0001-7248-6212

\section{Conflict of Interest}

The authors declare that there are no conflict of interest.

\section{Literature Cited}

Ahn, U. S., Y. K. Sohn, S. S. Kang, Y. M. Jeon and H. S. Choi. 2015. The major causes of Gotjawal formation in Jeju Island. Journal of the Geological Society of Korea 51: 1-19. (in Korean)

Cao, T., C. Gao, X. Li, D. Zhang, H. Si and D. H. Vitt. 2003. Moss Flora of China, Vol. 3. Science Press, Beijing and Missouri Botanical Garden Press, St. Louis, MO, 141 pp.

Choe, D. M. 1980. Illustrated Flora and Fauna of Korea, Vol. 24. Musci, Hepaticae. Ministry of Education, Seoul, 790 pp. (in Korean)

Choi, S. S. 2013. Taxonomy of the liverworts and hornworts in Korea. $\mathrm{PhD}$ dissertation, Jeonbuk National University, Jeonju, Korea, 604 pp.

Choi, S. S., V. A. Bakalin, C.-H. Kim and B.-Y. Sun. 2012. Unrecorded liverwort species from Korean flora II. Journal of Species Research 1: 218-223.

Choi, S.-S., V. A. Bakalin and B.-Y. Sun. 2010. The liverwort flora of Mt. Deogyu (Korea). In Bryoflora of the Russian Far East: Taxonomy, Genesis, Phytogeographic Relations. Far-Eastern National University, Vladivostok. Pp. 24-25.

Crandall-Stotler, B., R. E. Stotler and D. G. Long. 2009. Phylogeny and classification of the Marchantiophyta. Edinburgh Journal of Botany 66: 155-198.

Gao, C., X. Li, T. Cao, B. Lin, D. H. Vitt and H. Si. 1999. Moss Flora of China, Vol. 1. Science Press, Beijing and Missouri Botanical Garden Press, St. Louis, MO, 273 pp.

Glime, J. M. 2017. Adaptive strategies: growth and life forms. Retrieved Jul. 1, 2020, available from http://digitalcommons.mtu.edu/bryophyte-ecology/.

Goffinet, B., W. R. Buck and A. J. Shaw. 2009. Morphology, anatomy, and classification of the Bryophyta. In Bryophyte Biology. Goffinet, B. and A. J. Shaw (eds.), Cambridge University Press, New York. Pp. 55-138.

Inoue, H. 1974. Illustrations of Japanese Hepaticae I. Tsukiji Shokan Publishing Co., Ltd., Tokyo, 189 pp. (in Japanese)

Inoue, H. 1976. Illustrations of Japanese Hepaticae II. Tsukiji Shokan Publishing Co., Ltd., Tokyo, 193 pp. (in Japanese)

Iwatsuki, Z. 2001. Mosses and Liverworts of Japan. Heibonsha Ltd., Tokyo, 355 pp. (in Japanese)

Iwatsuki, Z. and M. Mizutani. 1972. Colored Illustration of the 
Bryophytes of Japan. Hoikusha, Osaka, 405 pp. (in Japanese) Jeju Special Self-Governing Province. 2009. Jeju Dialect Dictionary. Jeju Special Self-Governing Province, Jeju, 730 pp. (in Korean)

Jeon, Y. M., U. S. Ahn, C. G. Ryu, S. S. Kang and S. T. Song. 2012. A review of geological characteristics of Gotjawal terrain in Jeju Island: preliminary study. Journal of the Geological Society of Korea 48: 425-434. (in Korean)

Jeon, Y. M., D. S. Kim, J. S. Ki and J. G. Koh. 2015. A proposal for geological classification of Gotjawal terrain in Jeju Island and its meaning. Journal of the Geological Society of Korea 51: 235-241. (in Korean)

Jeong, K.-J. 2015. The past, present and future of Gotjawal: questions and proposals about the existence of Gotjawal. Journal of the Association of Korean Photo-Geographers 25: 15-32. (in Korean)

Kang, H. G, C. S. Kim and E. S. Kim. 2013. Human influence, regeneration, and conservation of the Gotjawal forests in Jeju Island, Korea. Journal of Marine and Island Cultures 2: 85-92.

Korea National Park Research Institute. 2016a. 2016 Natural Resources Survey of Sobaeksan National Park. National Park Research Institute, Korea National Park, Wonju, 788 pp. (in Korean)

Korea National Park Research Institute. 2016b. 2016 Natural Resources Survey of Gayasan National Park. National Park Research Institute, Korea National Park, Wonju, 674 pp. (in Korean)

Korea National Park Research Institute. 2018. 2018 Natural Resources Survey of Taebaeksan National Park. National Park Research Institute, Korea National Park, Wonju, 674 pp. (in Korean)

Korea National Park Research Institute. 2019a. 2019 Natural Resources Survey of Jirisan National Park (I). National Park Research Institute, Korea National Park, Wonju, 1794 pp. (in Korean)

Korea National Park Research Institute. 2019b. 2019 Natural Resources Survey of Sokrisan National Park. National Park Research Institute, Korea National Park, Wonju, 1417 pp. (in Korean)

Kürschner, H. 2004. Life strategies and adaptations in bryophytes from the Near and Middle East. Turkish Journal of Botony 28: 73-84.

Li, X., Z. Li, B. Lin, T. Cao, C. Gao, H. Si, D. G. Horton, Z. Iwatsuki, W. D. Reese and D. H. Vitt. 2001. Moss Flora of China, Vol. 2. Fissidentaceae-Ptychomitriaceae. Science Press, Beijing and Missouri Botanical Garden Press, St. Louis, MO, 283 pp.

Mägdefrau, K. 1982. Life-forms of bryophytes. In Bryophyte Ecology. Smith, A. J. E. (ed.), Chapman and Hall, London. Pp. 45-58.
Ministry of the Environment Government of Japan. 2020. 4th Red List of the Ministry of the Environment (in alphabetical order). Retrieved Jul. 1, 2020, available from https://www.env.go.jp/ press/files/jp/114458.pdf. (in Japanese)

Nakanishi, K. 2001. Floristic diversity of bryophyte vegetation in relation to island area. The Journal of the Hattori Botanical Laboratory 91: 301-316.

Noguchi, A. 1987. Illustrated Moss Flora of Japan 1. Daigaku Printing Co., Ltd., Hiroshima. Pp. 2-242.

Noguchi, A. 1988. Illustrated Moss Flora of Japan 2. Daigaku Printing Co., Ltd., Hiroshima. Pp. 243-491.

Noguchi, A. 1989. Illustrated Moss Flora of Japan 3. Daigaku Printing Co., Ltd., Hiroshima. Pp. 493-742.

Noguchi, A. 1991. Illustrated Moss Flora of Japan 4. Daigaku Printing Co., Ltd., Hiroshima. Pp. 743-1012.

Noguchi, A. 1994. Illustrated Moss Flora of Japan 5. Daigaku Printing Co., Ltd., Hiroshima. Pp. 1013-1253.

Shu, L., Y.-L. Xiang, X.-F. Cheng, Y.-M. Wei, J. Wang, L.-N. Zhang, W. Li, X.-B. Yin, W.-P. Zhang, C.-X. Zhao, T. Peng, T. V. Do, T. N. Lu and R.-L. Zhu. 2017. New liverwort and hornwort records for Vietnam. Cryptogamie, Bryologie 38: 411445.

So, M. L. 2001. Plagiochila (Hepaticae, Plagiochilaceae) in China. Systematic Botany Monographs 60: 1-214.

Song, S. T. 2000. Distribution and lithology of the Aa rubble flows in Cheju Island, Korea. PhD dissertation, Pusan National University, Busan, Korea, 118 pp. (in Korean)

Uyar, G., M. Alataş, M. Ören and T. Keçell. 2007. The bryophyte flora of Yenice forests (Karabük, Turkey). International Journal of Botany 3: 129-146.

Wu, P., B. Lin, C. Gao, T. Cao, Z. Li, B. C. Tan, H. Si, Y. Jia, M. Wang, X. Fu, J. Sun and B. Zhong. 2002. Moss Flora of China, Vol. 6. Science Press, Beijing and Missouri Botanical Garden Press, St. Louis, MO, 221 pp.

Yim, E.-Y., B.-K. Choi and H.-J. Hyun. 2019. Floristic study of bryophytes in Hangyeong Gotjawal (Cheongsu-ri), Jejudo Island. Korean Journal of Plant Taxonomy 49: 215-223.

Yim, E.-Y. and H.-J. Hyun. 2018. Floristic study of bryophytes in a subtropical forest of Nabeup-ri at Aewol Gotjawal, Jejudo Island. Korean Journal of Plant Taxonomy 48: 100-108.

Yim, E.-Y., M.-O. Moon, B.-Y. Sun and K. Nakanishi. 2013. Floristics of bryophytes in Dongbaek-dongsan at Seonheul Gotjawal. Korean Journal of Plant Taxonomy 43: 274-284.

Yoon, Y. J., C. H. Kim, K. V. Gorobets and B.-Y. Sun. 2011. The moss flora of Mt. Deogyu in Korea. Korean Journal of Plant Taxonomy 41: 287-297.

Yoon, Y. T. 2014. A humanities reflection on Got, Jawal and Gotjawal forest. Journal of Cheju Studies 41: 27-59. (in Korean) 
Appendix 1. Floristic list of bryophytes of evergreen broad-leaved forest in the vicinity of Baekyaki Oreum in Gujwa-Seongsan Gotjawal, Jejudo Island.

\begin{tabular}{|c|c|c|c|c|}
\hline Taxa & Korean name & Life form & Substrate & $\begin{array}{c}\text { Voucher No. } \\
\text { (Eun-Young Yim-) }\end{array}$ \\
\hline \multicolumn{5}{|l|}{ Bryophyta Schimp. 선류식물문 } \\
\hline \multicolumn{5}{|l|}{ Fissidentaceae Schimp. 봉황이끼과 } \\
\hline Fissidens gymnogynus Besch. & 작은봉황이끼 & Tall turfs & $\mathrm{L}$ & SSG324 \\
\hline \multicolumn{5}{|l|}{ Bryaceae Schwägr. 은이끼과 } \\
\hline Rosulabryum capillare (Hedw.) J. R. Spence & 철사이끼 & Short turfs & $\mathrm{L}$ & SSG072 \\
\hline \multicolumn{5}{|l|}{ Mniaceae Schwägr. 참이끼과 } \\
\hline Mnium ambiguum $\mathrm{H}$. Müll. & 납작맥초롱이끼 & Tall turfs & $\mathrm{L}$ & SSG178 \\
\hline Plagiomnium acutum (Lindb.) T. J. Kop. & 아기들덩굴초롱이끼 & Tall turfs & LS & SSG016 \\
\hline Plagiomnium cuspidatum (Hedw.) T. J. Kop. & 들덩굴초롱이끼 & Tall turfs & $\mathrm{L}$ & SSG006 \\
\hline Plagiomnium vesicatum (Besch.) T. J. Kop. & 큰잎덩굴초롱이끼 & Tall turfs & $\mathrm{L}$ & SSG095 \\
\hline Trachycystis microphylla (Dozy \& Molk.) Lindb. & 아기초롱이끼 & Tall turfs & LP & SSG108 \\
\hline \multicolumn{5}{|l|}{ Bartramiaceae Schwägr. 구슬이끼과 } \\
\hline Philonotis fontana (Hedw.) Brid. & 물가이끼 & Tall turfs & $\mathrm{S}$ & SSG073 \\
\hline \multicolumn{5}{|l|}{ Thuidiaceae Schimp. 깃털이끼과 } \\
\hline Anomodon minor (Hedw.) Lindb. & 푸른명주실이끼 & Tails & LP & SSG168 \\
\hline Claopodium aciculum (Broth.) Broth. & 가시이끼 & Wefts & $\mathrm{L}$ & SSG077 \\
\hline Haplocladium angustifolium (Hampe \& Müll. Hal.) Broth. & 침작은명주실이끼 & Wefts & LPXS & SSG003 \\
\hline Haplocladium microphyllum (Hedw.) Broth. & 작은명주실이끼 & Wefts & LP & SSG078 \\
\hline Pelekium versicolor (Hornsch. ex Müll. Hal.) Touw & 아기깃털이끼 & Wefts & LPXS & SSG008 \\
\hline Thuidium kanedae Sakurai & 깃털이끼 & Wefts & LPS & SSG007 \\
\hline Thuidium pristocalyx (Müll. Hal.) A. Jaeger & 푸른깃털이끼 & Wefts & $\mathrm{L}$ & SSG081 \\
\hline Thuidium subglaucinum Cardot & 큰푸른깃털이끼 & Wefts & $\mathrm{L}$ & SSG111 \\
\hline \multicolumn{5}{|l|}{ Brachytheciaceae Schimp. 양털이끼과 } \\
\hline Brachythecium buchananii (Hook.) A. Jaeger & 긴양털이끼 & Wefts & $\mathrm{L}$ & SSG083 \\
\hline Brachythecium helminthocladum Broth. \& Paris & 근양털이끼 & Wefts & $\mathrm{L}$ & SSG261 \\
\hline Brachythecium plumosum (Hedw.) Schimp. & 날개양털이끼 & Wefts & LP & SSG033 \\
\hline Brachythecium populeum (Hedw.) Schimp. & 양털이끼 & Wefts & LXS & SSG005 \\
\hline Bryhnia novae-angliae (Sull. \& Lesq.) Grout & 세모양털이끼 & Wefts & $\mathrm{L}$ & SSG018 \\
\hline Cirriphyllum piliferum (Hedw.) Grout & 겉근양털이끼 & Wefts & $\mathrm{L}$ & SSG032 \\
\hline Eurhynchium savatieri Schimp. ex Besch. & 가는부리이끼 & Wefts & LPXS & SSG087 \\
\hline Rhynchostegium pallidifolium (Mitt.) A. Jaeger & 아기양털부리이끼 & Wefts & LP & SSG153 \\
\hline \multicolumn{5}{|l|}{ Hypnaceae Schimp. 털깃털이끼과 } \\
\hline Callicladium haldanianum (Grev.) H. A. Crum & 풀이끼 & Wefts & $\mathrm{L}$ & SSG048 \\
\hline Pseudotaxiphyllum pohliaecarpum (Sull. \& Lesq.) Z. Iwats. & 빨간겉주목이끼 & Mats & LS & SSG096 \\
\hline Pylaisiadelpha tenuirostris (Bruch \& Schimp. ex Sull.) W. R. Buck & 무성아실이끼 & Mats & $P$ & SSG092 \\
\hline Taxiphyllum aomoriense (Besch.) Z. Iwats. & 겹친주목이기 & Mats & $\mathrm{L}$ & SSG144 \\
\hline Taxiphyllum taxirameum (Mitt.) M. Fleisch. & 주목이끼 & Mats & LPX & SSG058 \\
\hline
\end{tabular}


Appendix 1. Continued.

\begin{tabular}{|c|c|c|c|c|}
\hline \multicolumn{5}{|l|}{ Plagiotheciaceae M. Fleisch. 산주목이끼과 } \\
\hline Plagiothecium euryphyllum (Cardot \& Thér.) Z. Iwats. & 넓은잎산주목이끼 & Mats & $\mathrm{L}$ & SSG090 \\
\hline Plagiothecium nemorale (Mitt.) A. Jaeger & 산주목이끼 & Mats & LPX & SSG002 \\
\hline \multicolumn{5}{|l|}{ Entodontaceae Kindb. 윤이끼과 } \\
\hline Entodon challengeri (Paris) Cardot & 넓은잎윤이끼 & Wefts & $\mathrm{L}$ & SSG089 \\
\hline Entodon sullivantii (Müll. Hal.) Lindb. & 가는윤이끼 & Wefts & LPXS & SSG009 \\
\hline \multicolumn{5}{|l|}{ Sematophyllaceae Broth. 나무실이끼과 } \\
\hline Sematophyllum subhumile (Müll. Hal.) M. Fleisch. & 나무실이끼 & Mats & $\mathrm{X}$ & SSG093 \\
\hline Sematophyllum subpinnatum (Brid.) E. Britton & 날개무성아실이끼 & Mats & $\mathrm{PX}$ & SSG267 \\
\hline \multicolumn{5}{|l|}{ Neckeraceae Schimp. 납작이끼과 } \\
\hline Neckera humilis Mitt. & 아기납작이끼 & Fans & LP & SSG013 \\
\hline Pseudanomodon giraldii (Müll. Hal.) Ignatov \& Fedosov & 큰명주실이끼 & Tails & $\mathrm{L}$ & SSG075 \\
\hline Thamnobryum plicatulum (Sande Lac.) Z. Iwats. & 그늘대호꼬리이끼 & Fans & $\mathrm{L}$ & SSG088 \\
\hline Thamnobryum subseriatum (Mitt. ex Sande Lac.) B. C. Tan & 대호꼬리이끼 & Fans & $\mathrm{L}$ & SSG004 \\
\hline \multicolumn{5}{|l|}{ Marchantiophyta Stotler \& Crand. -Stotl. 태류식물문 } \\
\hline \multicolumn{5}{|l|}{ Wiesnerellaceae Inoue 방울우산이끼과 } \\
\hline Wiesnerella denudata (Mitt.) Steph. & 방울우산이끼 & Mats & $\mathrm{L}$ & SSG102 \\
\hline \multicolumn{5}{|l|}{ Dumortieraceae D. G. Long 털우산이끼과 } \\
\hline Dumortiera hirsuta (Sw.) Nees & 털우산이끼 & Mats & $\mathrm{L}$ & SSG103 \\
\hline \multicolumn{5}{|l|}{ Metzgeriaceae H. Klinggr. 리본이끼과 } \\
\hline Metzgeria lindbergii Schiffn. & 리본이끼 & Mats & LP & SSG182 \\
\hline \multicolumn{5}{|l|}{ Porellaceae Cavers 세줄이끼과 } \\
\hline Porella gracillima Mitt. & 가는세줄이끼 & Mats & $\mathrm{L}$ & SSG220 \\
\hline Porella grandiloba Lindb. & 큰세줄이끼 & Mats & $\mathrm{L}$ & SSG143 \\
\hline Porella vernicosa $\mathrm{Lindb}$. & 가시세줄이끼 & Mats & $\mathrm{L}$ & SSG001 \\
\hline \multicolumn{5}{|l|}{ Lejeuneaceae Cavers 작은귀이끼과 } \\
\hline Lejeunea japonica Mitt. & 작은귀이끼 & Mats & LPS & SSG204 \\
\hline \multicolumn{5}{|l|}{ Lophocoleaceae Müll. Frib. ex Vanden Berghen 두끝벼슬이끼과 } \\
\hline Heteroscyphus argutus (Nees) Schiffn. & 아기비늘이끼 & Mats & $\mathrm{L}$ & SSG099 \\
\hline Heteroscyphus planus (Mitt.) Schiffn. & 비늘이끼 & Mats & LP & SSG186 \\
\hline \multicolumn{5}{|l|}{ Plagiochilaceae Müll. Frib. 날개이끼과 } \\
\hline Plagiochila ovalifolia Mitt. & 둥근날개이끼 & Tall turfs & $\mathrm{L}$ & SSG046 \\
\hline Plagiochila sciophila Nees ex Lindenb. & 아기날개이끼 & Tall turfs & LX & SSG214 \\
\hline Plagiochila shangaica Steph. & 해안날개이끼 & Tall turfs & LP & SSG107 \\
\hline \multicolumn{5}{|l|}{ Cephaloziellaceae Douin 겉게발이끼과 } \\
\hline Cephaloziella spinicaulis Douin & 가시겉게발이끼 & Mats & $\mathrm{L}$ & SSG148 \\
\hline \multicolumn{5}{|l|}{ Jungermanniaceae Rchb. 망울이끼과 } \\
\hline Jungermannia infusca (Mitt.) Steph. & 큰망울이끼 & Mats & $\mathrm{L}$ & SSG173 \\
\hline
\end{tabular}

L, epilithic; P, epiphytic; X, epixylous; S, on the soil. 